\title{
Gaan na die mier, kyk na sy weë en word wys: Metafoor of paradigma?
}

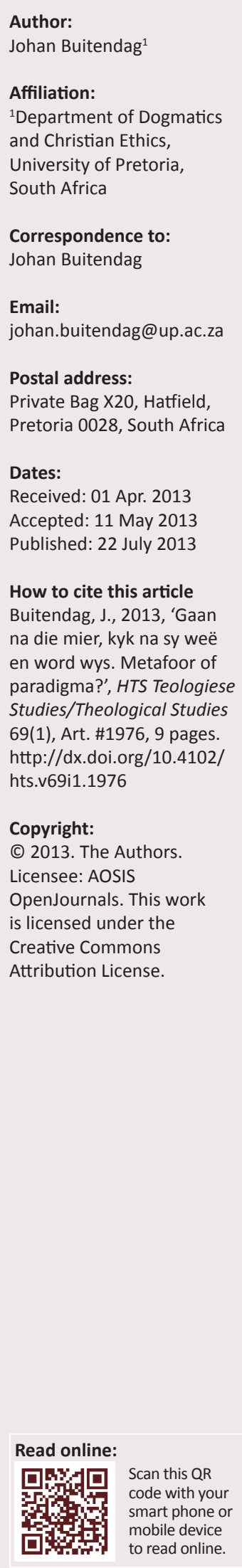

Go to the ant, consider her ways, and be wise. Metaphor or paradigm? This article takes as its point of departure two citations. The one is from Marshall and Zohar's contention that the wave-particle dualism is more than a metaphor and the other is from Clayton claiming that indeterminacy was not merely a temporary epistemic problem, but reflected an inherent indeterminacy of the physical world itself. What does it mean if it is not a mere way of speaking? The author of this article departs from the premise that the task of systematic theology is the endeavour to understand reality and that this is a collective enterprise together with other sciences as well. A constructive empiricism could indeed lead to an understanding of reality where reality is more than merely idealistically conceived. Truth is therefore to be replaced with a pragmatic, but value-laden concept of understanding or comprehension. This has the effect that both epistemology and ontology have to be revisited and subsequently panentheism too. The argument finds its niche in Old Testament wisdom literature and Proverbs 6:6 forms the lens of reference. The late South African ethologist Eugène Marais's epic work, The Soul of the Ant, is applied to illustrate such a proposed epistemic community.

\section{Inleiding}

'n Opmerking wat ek dekades gelede teëgekom het, bly my in my teologiese nadenke fassineer. Dit is Zohar en Marshall (1994) se stelling dat die kwantumfisika se golf en/of partikel beskrywing van die werklikheid, meer as net ' $n$ metafoor is:

The wave-particle dualism in self or society is a powerful metaphor on which we can build a new model to transcend the individualist/collectivist divide, but I believe it is more than a metaphor. I believe that human consciousness really is quantum mechanical in its origins, and that the mechanics of this quantum consciousness literally give our minds, our selves and our social relations both a wave aspect and particle aspect. (bl. 82)

Ongeveer 'n soortgelyke gevolgtrekking word deur Clayton (2004:85) gemaak wanneer hy skryf dat die, 'Copenhagen theorists came to the startling conclusion that quantum mechanical indeterminacy was not merely a temporary epistemic problem but reflected an inherent indeterminacy of the physical world itself.'

Albei hierdie kursief gedrukte woorde (oorspronklik so) in bogenoemde aanhalings is ontologiese uitsprake wat iets oor ons werklikheidsverstaan wil sê. In sy eie konteks, huldig Polkinghorne (2005b:336) dieselfde opinie, 'they cannot be downgraded into mere ways of speaking.' Dit wil inderwaarheid die indruk skep dat ons moet teruggaan na 'n werklikheidsverstaan vóór Kant waar dinge aangebied word nie soos dit voorkom nie, maar soos dit kwansuis is.

Sistematiese Teologie is vir my werklikheidsverstaan. Dit impliseer'n ellips met twee brandpunte: 'n ontologiese en 'n epistemologiese. Dit is uiteraard 'n subjektiewe aktiwiteit (die teoloog as jongleur ${ }^{1}$ ), maar tegelyk ook 'n komprehensiewe onderneming wat holisties neig. My oortuiging is dat naas die sosiale- en gedragswetenskappe, ook die natuurwetenskappe die teologie kan help vorm aan 'n grammatika om die werklikheid meer komprehensief te verstaan. John Haught (2012:30) skryf byvoorbeeld in sy nuutste boek dat natuurwetenskaplike ontdekkings ons inderdaad kan lei om sinvol ook oor God te praat en as illustrasie verwys hy na die ontdekking van die kosmos as 'n oneindige uitgebreide en ontvouende verhaal ('immensely long and unfolding story'). Persoonlik is ek ook bereid om saam met Arthur Peacocke (2004) te waag:

We have to emphasize anew the immanence of God as creator 'in, with, and under' the natural processes of the world unveiled by the sciences in accord with all that the sciences have revealed since those debates in the nineteenth century. (bl. 143)

Waarop ek afstuur is dat teologie moet terugkom aarde toe. Moltmann (2003) sê dit nogal treffend:

Theology must abandon its confinement to church, belief and the awareness of the heart, so far that with all others it may search for the truth of the whole, and the salvation of a torn and disrupted world. (bl. 7)

1.Sien hiervoor my eksposisie van L.J. van den Brom se werklikheidsverstaan, Buitendag (2012a) 
Dit is duidelik dat daar in die teologie toenemend ' $n$ beweging is weg van die 'loodregte ingryp van $\mathrm{Bo}^{\prime 2}$ na 'n ontluikende bewussyn van 'n sosiale en natuurlike netwerk waarbinne ek 'tot verhaal kom'. ${ }^{3}$ Teoloë moet saam met natuurwetenskaplikes nadink oor die werklikheid en as't ware aposteriories met God se teenwoordigheid omgaan. So ontwikkel teologie tot ' $n$ verantwoordbare ordenings- en interpretasiesisteem van die werklikheid.

Sekere theologoumena in die dialoog tussen teologie en natuurwetenskap vertroebel eenvoudig die gesprek. Hierdie artikel handel nie per se oor God en openbaring nie, maar oor die moontlikheid of die empiriese werklikheid nie ook intrinsieke waarhede bevat wat vir die gelowige waarde het in sy of haar werklikheidsverstaan en wat as gemeenskaplike grond in die dialoog met natuurwetenskap kan funksioneer nie. Dit is dus nie maar net nog 'n vorm van apologetiek wat bloot redelik met die geloof wil omgaan nie, maar wil die werklikheid probeer verstaan deur waarneming of onderskeiding as spirituele praktyk. Aquinas (2009, STh., I q.87 a.3 ad2) het hierdie opsie al aangebied dat waarneming en interpretasie nie geskei nie, maar hoogstens onderskei moet word: 'Hence the act whereby the intellect understands a stone is distinct from the act whereby it understands that it understands a stone.' Dit sluit aan by Alston (1993) se konsep waar 'n ervaringsmatige bewussyn van God bestaan en God juis ook waargeneem of onderskei moet word. Konstitutief in hierdie hele betoog bly natuurlik steeds die habitat of 'n eko-teologiese nis (Buitendag 2012c) as verstaanshorison.

'Gaan na die mier ... kyk na sy weë en word wys' (Spr 6:6). Is hierdie nie dalk ook meer as net 'n wysheidspreuk nie? In die gees van die twee openingsaanhalings kan dus gevra word of ons nie dalk ook hier met 'n werklikheidsgegewe te doen het nie? Is die aktiwiteite van die mier bloot aansporing tot menslike vlyt of is dit dalk ook ' $n$ afgeleesde paradigma van die werklikheid self? Het ons hier met bloot ' $n$ voorbeeld uit die skepping te doen of dalk ook met ' $n$ oerbeeld van die natuur? Alhoewel die gangbare uitleg van hierdie teksvers natuurlik op die vlytigheid van miere verwys en die mens teen luiheid waarsku - 'there is no option but to work' (Barth 2004:472) - wil ek eerder hieruit 'n grondmetafoor put wat deur natuurwetenskaplike evidensie ontwikkel is, naamlik die kommunale of korporatiewe funksionering van die mier.

Eugène N. Marais word wêreldwyd geag vir sy empiriese navorsing wat hy aan die begin van die twintigste eeu veral op die plaas Rietfontein in die Waterberg op die gebied van die etologie en die entomologie uitgevoer het. Twee belangrike publikasies het hieruit gevolg. In 1927 verskyn sy The soul of the ape (nadat die manuskrip lank soek was) en in 1934 publiseer hy Die siel van die mier. Dit word ook vandag algemeen aanvaar dat sy teorie dat die termietnes as 'n organiese eenheid opgeneem moet word, die basis

2.Perpendicular lines from above can render it in some measure intelligible and clear as we have already demonstrated, what takes place between God the Creator and the creature as God's royal dominion on the one side, and creaturely existence, life the creature as God's royal dominion on the one side, and creaturely existe

3.'With postliberal theology, the revelation of the Christian faith is a particula commitment to a particular narratival understanding of reality' Michener (2013:5) gevorm het vir die Belgiese skrywer Maurice Maeterlinck se navorsing en waarvan die Engelse vertaling The life of the white ant heet en op grond waarvan hy ook die Nobelprys later verower het (Marais 2007:21-22). Deur waarneming, eksperiment en nabetragting, kom Marais tot die oortuiging dat daar in die natuur bepaalde grondbeginsels is wat as't ware 'bestier'.

Dit bring my by die laureatus van hierdie Festschrift uit. In die voorwoord van Band 7 van die Wiener Alttestamentliche Studien, ter ere van James Alfred Loader se 65ste verjaarsdag, skryf die redakteurs, 'Weisheit und Schöpfung markieren zwei wichtige Kristallisationspunkte gegenwärtiger Forschungen am Alten Testament' (Fischer \& Grohmann 2010). Skepping en wysheid is inderdaad ook van die vernaamste foci wat ek nog altyd met Loader se teologie geassosieer het en wat ek in hierdie artikel wat ek aan hom opdra, ook wil hanteer. James Barr (1994), een van Loader se groot leermeesters, het destyds korte mette met Barth se onverbiddelike verwerping van 'n theologia naturalis gemaak en daarmee het Loader hom ook vereenselwig. Loader se liefde vir die skepping blyk veral uit sy belangstelling in natuurbewaring en is hy vandag nog 'n ereveldwagter van die Nasionale Krugerwildtuin. As kenner van die wysheidsliteratuur van die Ou Nabye-Ooste sal hy dus aanklank vind by Eugène Marais (2007:28) wat in Die siel van die mier sy empiriese ondersoek georiënteer het met ' $n$ teks uit die wysheidsliteratuur: 'tot die uiterste grens deursoek hy' (Job 28:3). 'n Teologiese verdiskontering van die siel van die mier is mý huldeblyk aan James Alfred Loader.

\section{Prolegomena}

Dit is interessant dat die klassieke verdeling tussen teologie en natuurwetenskap, naamlik dat teologie haar met die oorsprong- en bestemmingsvraag besig hou en natuurwetenskap weer met die voorhande werklikheid, vandag toenemend vervaag. Stephen Hawking byvoorbeeld is duidelik daaroor dat filosofie dood is en dat fisika hierdie vrae nou moet oorneem: 'Scientists have become the bearers of the torch of discovery in our quest for knowledge' (Hawking \& Mlodinow 2010:5). Opmerklik veral is sy onderliggende epistemologie. Hy beweer dat die tyd verby is dat wetenskaplike kennis slegs op waarneming gebaseer kan word. Hy staan gevolglik 'n model-dependant realism voor wat van die aanname af vertrek dat ons brein 'n bepaalde model van die werklikheid uit sensoriese waarneming ontwikkel (Hawking \& Mlodinow 2010:7). Sodanige modelle is egter nooit afgehandel nie en word algaande met meer bevredigende alternatiewe verfyn of selfs vervang. Dit moet eventueel na die sogenaamde Grand Unified Theory (GUT) lei wat alles afdoende verklaar en wat enige moontlike eksterne ingreep in die heelal - ook van God - volstrek uitsluit:

If the histories of the universe in imaginary time are indeed closed surfaces, as Hartle and I proposed, it would have fundamental implications for philosophy and our picture of where we came from. The universe would be entirely self-contained, it wouldn't need anything outside to wind up the clockwork and set it going. Instead, everything in the universe would be determined by the laws of science and by rolls of dice within the universe. This may sound presumptuous, but it is what I and many others scientists believe. (Hawking 2001:85) 
Hierdie epistemologie is in skrille kontras met David Hume se 'critical thought' wat uitsluitlik op empiriese waarneming gegrond is. Ons bewussyn kan net met feite omgaan, meen hy. Refleksie kan geen betekenis toevoeg wat feite nie reeds bied nie. As ' $n$ saak nie tot sintuiglike waarneming teruggevoer kan word nie, is dit wat Hume betref, metafisika en moet dit uitgeban word. Hy ag dit as 'n ontoelaatbare sprong om algemene uitsprake te maak wat op besondere feite berus. Omdat sommige $S=P$, beteken dit nie dat alle $S=P$ nie en omgekeerd, uit alle $M=P$, kan nie proefondervindelik lei na 'n uitspraak dat sommige $S=M$ nie. Empiries is dit gewoon onmoontlik om algemene uitsprake te maak omdat geen bewys bestaan dat die huidige $\mathrm{S}$ of $\mathrm{M}$, altyd dieselfde was of sal wees nie. Tog oordeel Trundle (1994:202) dat Aristoteles se metafisika nie geheel en al deur Hume se kritiese denke omvergegooi is nie. Daar is wel 'n verantwoordelike roete vanaf die besondere na die algemene toe. Hume bied immers sý waarneming aan as algemeen!

Die Suid-Afrikaanse filosoof, Martin Versfeld se refleksie oor evolusionêre kennis neem hierdie gedagte eerder in die rigting waarin ek beweeg: 'We are attempting to reconstruct what anteceded experience as if we had experienced it' (Versfeld 2010:191). Herinnering en antisipasie is voortdurend in spel met die hede (Augustinus). Dit word moontlik gemaak omdat die wêreld met al sy beperkinge inderwaarheid 'n wêreld van relasies en interaksies is. Om beperk te wees, is egter nie om geïsoleerd te wees nie:

We may say, then, that every finite thing is acted on by or suffers its environment; reflects or mirrors it from its own point of view; and reacts upon it, that is, impresses its structure as a perspective upon other things. (Versfeld 2010:206)

Die grens tussen teologie en wetenskap vervaag nie net wat ons kenleer betref nie, maar ook wat die natuur betref. Klassieke teïsme maak 'n essensiële verskil tussen Skepper en skepping: God is noodwendig en die skepping kontingent; God woon in die hemel en ons op die aarde; God woon in die ontoeganklike lig. Tradisioneel het die dogmatiek dan ook geleer dat die skepping volstrek van God afhanklik is sowel vir die ontstaan as die voortbestaan daarvan. Iemand soos Diogenes Allen (1985:1-3) maak heelwat gewag daarvan om aan te toon dat daar ' $n$ substansiële onderskeid tussen Skepper en skepping is en dat juis dít die verskil tussen Genesis se skeppingsverhale en Aristoteles se metafisika is. Vir laasgenoemde gaan dit gewoon om die orde in die dinge rondom ons waar te neem en glad nie om die oorsprong van alles te verklaar nie. Aristoteles wou bloot die bepaalde beginsels blootlê wat in die natuur aanwesig is. En daarom kan Allen (1985:3) onomwonde verklaar dat:

in contrast to Aristotle, the claims made by Genesis and the rest of Scriptures of ancient Israel do not spring from a desire to discover the principles of nature's operation, nor even to account for the existence of the universe. (bl. 3)

Soos wat Hawking meen die natuurwetenskappe ook met die oorsprongsvraag gemoeid is, is dit ook toenemend duidelik dat teologie op haar beurt, weer met die voorhande werklikheid worstel.
Hierdie afgrensing teenoor Aristoteles se metafisika is ook sterk by Eberhard Jüngel op te merk in sy boek met die veelseggende titel, Gott als Geheimnis der Welt. Ook hy maak 'n saak daarvoor uit om Reformatoriese teologie af te grens teenoor 'n Aristoteliaanse werklikheidsverstaan. Hy oordeel dat die idee van God as aktualiteit primêr behoort te wees:

Deshalb denken wir Gott in Einheit mit der Vergänglichkeit. Und darin bestreiten wir den aristotelischen Grundansatz der abendländischen Metaphysik, der der reinen Wirklichkeit einen ontologischen Primat vor der Möglichkeit zusprach und damit der Vergänglichkeit notwendig eine ausschlieszlich negative ontologische Qualität zusagte. (Jüngel 1977:291)

Belangrik egter is dat iemand soos Michael Welker hom gedwonge voel om hierdie pertinente standpunt van Jüngel te kwalifiseer. Hy oordeel dat Jüngel eerder in 'n afgeleide sin hierdie konsep van Aristoteles kritiseer en die bedoeling daarvan dus mis (Welker 1994:298). Hy meen Jüngel lees onregmatig selfaktualisering as 'n teenwoordige deelwoord in die filosofie van Aristoteles in: 'By contrast, Aristotelian metaphysics conceives the intellectual self-actualization that stands at its center as a living power that can definitely claim to stand in union with perishability and with possibility' (Welker 1994:299). Die self van die selfaktualisering word met ander woorde nie resloos daarin opgelos nie. Welker is gevolglik van mening dat Jüngel nie nodig gehad het om sy teologie so sterk teen Aristoteles af te grens nie en dat hy sy program ewenwel mét Aristoteles se metafisika sou kon voltrek. Hierdeur oordeel hy het Jüngel sy eie teologie skade berokken deurdat hy aktualiteit en potensialiteit eerder geskei as onderskei het. God en wêreld is nie so van mekaar te isoleer nie, meen Welker en by implikasie dus ook, Jüngel. Op spoor van Hegel wil Welker (1994:302) dus tog sê: 'Spirit has thereby entered into perishability.' Skepper het skepping geword.

Die toepaslikheid van hierdie argument in die onderhawige betoog, kom duidelik na vore in Welker se eksegese van die skeppingsverhale van die boek Genesis. Hy toon aan dat hierdie skeppingsverhale glad nie die verhouding tussen Skepper en skepping sien soos die van subjek en objek, van aksie en passie nie. Inteendeel, genoegsame eksegetiese gronde bestaan volgens hom om juis aan te toon dat die omgekeerde eerder die geval is. Aksie gaan ook van die skepping af uit en reaksie ook van God af uit (Welker 1999:9-13). Ons moet God dus nie as die verhewe God wat in Selfgenoegsaamheid tot skepping oorgegaan het beskou nie. Trouens, Welker (1999:12) meen dat, 'we do not arrive at a clear differentiation of God's activity and the creature's activity in the process of creation.' Skeppingswerk is derhalwe die totstandkoming en die instandhouding van 'n kombinasie van onderskeibare sfere van skepping. Hierdie sfere is wedersyds sowel toeganklik as ontoeganklik. Kennis van die skepping sal daarom altyd beperk wees, alhoewel nie ónredelik nie (Welker 1999:32).

'n Substantiewe ontologie gaan vandag eenvoudig net nie meer op nie (Peacocke 2004:145). Hierdie Goddelike ingrepe 'van Bo' bevredig nie meer die kritiese gees van wetenskap nie. Die probleem is immers dat Skepper en skepping nie 
unieke ontologiese identiteite kan behou as die skepping ook gesien word as deur God omvat word en deur God beheer word nie. Juis daarom het Moltmann (1985:98-105) baie vindingryk geredeneer dat God Godself eers moes onttrek, alvorens die skepping kon plaasvind. Hy ontleen die begrip zimzum om dit te verduidelik. As God voor die skepping oral was, moes die skepping mos in God plaasgevind het (emanasie) en daarom moes God eers die Niks geskep het daar waar God níe is nie - alvorens God kon skep. Dit is dus nie net ' $\mathrm{n}$ kwessie van skepping ex nihilo nie, maar ook van skepping annihilatio nihili of selfs in nihilo.

Polkinghorne (2005b:337) maak die uiters belangrike opmerking dat ontologie en epistemologie so ineengestrengel kan raakdatditmaklikverwarword.HygebruikHeisenbergse onsekerheidsbeginsel in kwantumfisika om dit te illustreer en meen dat wat aanvanklik'n epistemologiese veronderstelling gehad het (ons kan nie posisie en momentum gelyktydig kén nie), verkeerdelik 'n ontologiese aangeleentheid gemaak is (posisie en momentum kan nie gelyktydig wéés nie) (Polkinghorne 1998:31). Onsekerheid in hierdie sin was dus eerder gesien as onkundigheid. Heisenberg het volgens hom bedoel dat die kwanta sowel die eienskap van momentum as posisie potensieel het, maar dat 'n eksterne ingryp dit tot slegs een eienskap forseer. Onsekerheid (epistemologie) is toe verkeerdelik as onbepaalbaarheid (ontologie) opgeneem (Polkinghorne 2005a:85). Tog is Polkinghorne 'n (kritiese) realis en is sy geliefde spreuk, 'epistemology models ontology', wat vir hom sê dat wat mens kan ken, juis die werklikheid is en ' $n$ bepaalde korrespondensie daartussen bestaan. In ' $n$ analise van Polkinghorne se slagspreuk dat epistemologie altyd ontologie modelleer, het ek aangetoon dat die saak eerder van albei rigtings te verstaan is en dat omgekeerd, ontologie ook epistemologie bepaal (Buitendag 2012b). Dit is dalk nie eers net 'n hoender-en-eier kwessie van wat eerste en wat tweede is nie, maar selfs amper roereier wat nie meer ontwar kan word nie:

Epistemological considerations will have to become part of its substance, and what it states will have to be stated in a way which makes explicit the viewpoint from which it is stated. (Versfeld 2010:231)

Celia Deane-Drummond (2006:64) reflekteer in dieselfde gees oor Spreuke 6:6 en oordeel dat dit in hierdie teks nie alleen om fyn waarneming van die miere en hulle gedrag gaan nie, maar ook verder gaan en die wyse ('way') bedink wat dit is om ' $\mathrm{n}$ mier te wees. Dit beteken dat 'discernment' op 'seeing' moet volg en dat hierdie proses tot wysheid lei. Dit is dus nie bloot waarneming nie, alhoewel daarmee begin word, maar dit moet lei na 'n empatiese 'feeling for the organism.' Wysheid word dus nie net raakgesien nie, maar geïnterpreteer. Maar tog is dit geen ingeleesde wysheid nie, wel afgeleesde wysheid wat ontloot, soos ek die volgende aanhaling van Norman Habel verstaan en waarop Deane-Drummond haar argument ook baseer:

The physical universe, it seems, is a complex of components, each of which has a distinctive 'law', 'way', 'place' or 'dimension' that characterises it in relation to the rest of the cosmos. Ultimately, this mysterious distinctive feature can also be designated the wisdom in that thing itself. All phenomena of Earth, it seems, have wisdom within them; wisdom is not only something humans acquire by observing nature. It also seems to be something imbedded in nature that humans are challenged to discover. (Habel 2004:59)

Dit behoort duidelik te wees dat die klassieke onderskeiding tussen teologie en natuurwetenskap toenemend in onguns verval. Wanneer Sally McFague na modelle vra om oor God te praat, is haar metodologie analoog aan Stephen Hawking se soeke na 'n GUT (kyk bo). In McFague (1982:28) se verwysing is die reeks metafoor $\rightarrow$ model $\rightarrow$ konsep duidelik te identifiseer, waar sy dan kies vir 'n model. Sy verkies ook Ricoeur se korreksie op Gadamer wat dus nie 'n hermeneutiek van 'suspisie' aanbied nie, maar ' $n$ hermeneutiek van 'herinnering en herstel' of rekonstruksie (McFague 1982:63-64). Dit bring haar tot die belangrike gevolgtrekking vir ook my betoog: 'to be a believer is to be on a continuum with being human' (McFague 1982:65), of soos reeds gesê, menswees is ' $n$ ontluikende bewussyn van 'n sosiale en natuurlike netwerk waarbinne ek tot verhaal kom.

Ek is opgewonde oor ' $n$ aanhaling van Alvin Plantinga wat wetenskap en teologie baie nader aanmekaar beskou as wat allerweë toegegee wil word en daartoe byvoeg, dat wetenskap en naturalisme weer baie verder uitmekaar as wat besef word: 'There is superficial conflict but deep concord between science and theistic religion, but superficial concord and deep conflict between science and naturalism' (Plantinga 2011:i).

\section{'Deur Hom lewe ons, beweeg ons en bestaan ons'}

Beteken dit nou dat so kwalik ons die kennende subjek en die gekende objek uitmekaar kan ontwar, ons dit ook nie met Skepper en skepping kan doen nie? Is panteïsme gevolglik ons voorland? Nee, die feit dat die Gees die aarde vul en alles bymekaar hou, beteken nie dat God in die skepping opgelos word nie.

To experience God in all things presupposes that there is a transcendence which is immanent in things and which can be inductively discovered. It is the infinite in the finite, the eternal in the temporal, and the enduring in the transitory. (Moltmann 1994:34)

Die inwoning van God in die skepping - die schechina verseker God se onafhanklike teenwoordigheid. Moltmann wil met sy Trinitariese skeppingsbegrip juis God se transendensie van en immanensie in die wêreld bymekaar uitbring. Hy vind die begrip panenteïsme baie geskik om hierdie ooreenkoms in die verskil en die verskil in die ooreenkoms aan te dui (Moltmann 1985:109). 'n 'Geïntegreerde geheelprentjie' van God en natuur kan vir die skepping net bevrydend wees.

Karl Heim (1926:458) het al honderd jaar gelede gesê dat die koppelwoordjie en die eintlike punt van debat tussen teologie en wetenskap is. Skepper en skepping, siel en liggaam, gees en stof, hemel en aarde, genade en natuur, lewe en dood, noem maar op, stel ons voor 'n geweldige uitdaging. Aan die een kant is die gevaar dat ons in 'n monisme kan verval (panteïsme, waar Skepper $=$ skepping) en aan die ander kant 
weer is die gevaar groot dat ons onsself in 'n dualisme (supranaturalisme, waar Skepper $\neq$ skepping) kan bevind. Die antwoord lê ook nie iewers in die middel nie, maar wel in 'n derde opsie wat enige gewone logika oorstyg ('n begrip waar Skepper > skepping en dus waar Skepper - skepping $\neq$ $0)$. Panenteïsme slaag inderdaad daarin om voorwaardes te integreer en is iemand soos Clayton (2004:87) ook heeltemal bereid om onomwonde te verklaar, 'I find panentheism to provide the most adequate means available.'

Gregersen (2004:19-20) kwalifiseer egter geredelikerwys dat hierdie konsep van panenteïsme op sigself onstabiel is en 'n bepaalde referent of tipologie (soos hy dit noem) benodig. Minstens dra die begrip darem oor dat God in die skepping is sonder om daarin opgelos te word. God hoef ook nie in die proses onpersoonlik verstaan te word nie. Hy (Gregersen 2004:21) onderskei gevolglik drie verwysingskaders waarbinne die begrip panenteïsme aangetref word en dat 'n subjektiewe keuse uiteindelik gemaak moet word. In kort kom dit neer op 'n Christologiese, 'n Pneumatologiese en 'n Prosesfilosofiese verstaan van panenteïsme. Die eerste is die oortuiging dat wie in Christus is, het God ook in hom of haar; die voorvoegsel 'al' (Grieks: pan) dui dus op die vrugte van die Gees in die lewe van die gelowige en is dus tog eksklusief. Die tweede opsie oorstyg hierdie antroposentriese fiksering en dui op die Gees wat van God na die skepping toe uitgaan en weer na God terugkeer; die voorvoegsel 'al' is hier dus 'n eskatologiese begrip wat eers met die herskepping sal realiseer. Laasgenoemde is op spoor van Whitehead, dipolêr waar God sowel tyd- en ruimteloos is as tydruimtelik gebonde; hier word die betrokke voorvoegsel egter bedenklik omdat dit enersyds God se identiteit onpersoonlik verskraal en andersyds boosheid ontologiese erkenning gee. Panenteïsme is gevolglik alleen bruikbaar, solank die klassieke Lutherse uitspraak van finitum capax infiniti gehandhaaf word en wat wil oordra dat God + natuur = natuur, terwyl natuur - God $=0$ (Gregersen 2004:35). Daarom is Clayton (2004:82) dus reg wanneer hy sê dat panenteïsme die skarnier is tussen 'n 'infinity-based ultimate unity' en 'n 'perfection-based irreducible pluralism.'

Die preposisie in van panenteïsme vra natuurlik ook aandag. Letterlik sê die woord dat 'alles is in God' en klink dit na 'n parafrase van Handelinge 17:27-28: 'Hy is nie ver van enigeen van ons af nie, want deur Hom lewe ons, beweeg ons en bestaan ons.' Verstaan ons ruimte egter in die klassieke Griekse sin van die woord as 'n houer, kan die sinsnede nie omgedraai word na 'God is in alles' nie. 'n Koppie kan nie in die kas wees en die kas tegelyk in die koppie nie! Ons moet egter ons ruimtebegrip dekonstrueer en die bydrae wat Thomas Torrance in hierdie verband gemaak het, is uiters toepaslik. Plato het volgens hom ruimte beskou as 'n oorkoepelende grootheid tussen die wêreld van bewussyn en die wêreld van sintuiglike waarnemings (Torrance 1997:5). Dit het aan ruimte 'n metafisiese noodwendigheid gegee wat alle begrip letterlik omvat en bymekaar hou. Aristoteles het Plato ook hierin gevolg en ruimte as ' $n$ kategorie gesien waarbinne iets bestaan. Dit maak ruimte 'n begrensde plekaanduiding waarin alles bestaan en beweeg. Ek wil Torrance (1997:9) ondersteun wat eerder die oplossing by die Stoïsyne gesoek het en wat ruimte nie as 'n houer gesien nie, maar as geleë in die liggaam self 'as an agency creating room for itself and extending through itself, thus making the cosmos a sphere of operation and place.' Met so 'n begrip van ruimte gaan dit dus nie om wie omvat en/of bevat wie nie, maar om die werking van God wat skeppend teenwoordig is. Ruimte word 'n funksie van selfbewussyn. Dit is 'n gebeurewoord. Mutatis mutandis het hierdie dekonstruksie ook plaasgevind met Newton se verstaan van absolute ruimte en Einstein se algemene relatiwiteitsteorie: 'Einstein's general theory of relativity transformed space and time from a passive background in which events take place to active participants in the dynamics of the universe' (Hawking 2001:21).

Dit is reeds genoem dat die klassieke verstaan van ontologie as synde 'n isoleerbare substansie vandag ook nie die laaste woord spreek nie. Allen (1985:93-103) bied 'n baie bevatlike uiteensetting van Aristoteles se Kategoriee aan en toon aan hoedat dit juis die matrys vir die Westerse teologie se Triniteitsleer gevorm het. Die wese van God (eenheid) is die primêre substansie en die drie Persone (veelheid) is die sekondêre substansie. Gregorius aan die ander kant, het die primêre substansie in die Persoon (veelheid) geplaas en die wese (eenheid) weer sekondêr gemaak. Alhoewel Allen dit nie grafies voorstel nie, meen ek tog dat my meegaande skets dit duideliker maak (Figuur 1).

In die afgelope dekades was dit veral teoloë soos John Zizioulas en Miroslav Volf wat die Kappadosiërs se Triniteitsleer verder ontgin het. Cristoph Schwöbel (1995:5) sê ook prontuit dat hedendaagse Triniteitsteologieë baie krities teenoor Augustinus se aanbod in hierdie opsig raak. Dit sou die betoog in hierdie artikel toereikend dien as hier nou net daarop gewys word dat hierdie benadering as't ware 'n nuwe ontologie daarstel deurdat dit met veelheid begin en die wedersydse deurdringing (perichoresis) van die Drieeenheid substansieel daarstel. Dit beteken dat die syn nou nie in isoleerbare substansies setel nie, maar in verhoudings. Nie die natuur van iets (die wat) maak saak nie, maar die wyse (die hoe) waar om dit gaan (Zizioulas 2006:23). Op hierdie manier word Skepper en skepping ook bymekaar uitgebring vanweë andersheid en gemeenskap. Dit voer na 'n 'ontology of love understood in a personal way' (Zizioulas 2006:29). Op spoor van Moltmann kan Leonardo Boff boonop byvoeg: 'The ultimate root of our history is found in the inner history of

\begin{tabular}{|c|c|c|c|c|c|}
\hline \multirow{5}{*}{$\begin{array}{l}\text { Gregorius } \\
\text { Augustinus }\end{array}$} & \multirow{2}{*}{\multicolumn{2}{|c|}{$\begin{array}{c}\text { Substansies } \\
\text { Subjek } \\
\end{array}$}} & \multirow{5}{*}{ 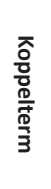 } & \multirow{2}{*}{\multicolumn{2}{|c|}{$\begin{array}{c}\text { Differentia } \\
\text { Predikaat }\end{array}$}} \\
\hline & & & & & \\
\hline & Primêr individueel & Sekondêr genera & & Aksidente identifiseer & Essensies definieer \\
\hline & Persoon & Wese & & Drie & Een \\
\hline & Wese & Persoon & & Een & Drie \\
\hline
\end{tabular}

FIGUUR 1: Triniteitsverstaan soos gebaseer op Aristoteles se ontologie. 
the Trinity, the play of mutual relations among the divine Three, eternally producing diversity and unification' (Boff 2000:105).

Philip Clayton (2004:87) oordeel dat emergence die mees geskikte konstruk is om panenteïsme, oftewel dan die immanensie van God in die skepping te verduidelik. Weliswaar ' $n$ konsep van die natuurwetenskap, voorsien dit ook taal aan die teoloog om op induktiewe wyse by die kategorie van geestelikheid en Goddelikheid uit te kom. Hiermee word gepoog om by God van binne af te kom. Peacocke (2004:140) verduidelik dat die mens soos die Hebreërs as 'n geanimeerde liggaam gesien moet word en nie as 'n beliggaamde siel nie. Die uitdaging is nou om die menslike persoon te beskou as brein-in-die-menslike-liggaam-indie-gemeenskap-in-die natuur. In sy boek met die veelseggende titel, Paths from science towards God, beredeneer Peacocke (2002) 'n model om God se betrokkenheid in die wêreld te verstaan, te wete as ' $n$ 'whole-part' aktiwiteit. Daar is ' $n$ bepaalde wisselwerking tussen die deel en die geheel en is hy bereid om die heelal as 'n oorkoepelende sisteem van sisteme te beskou. Sonder om die wêreld nou as God se liggaam te wil verstaan (daarvoor het hy ook afstand geneem van 'n klassieke ruimtebegrip), wil hy wel beklemtoon dat God invloed op die skepping het. Peacocke voer die belangrike beweging uit om die ontologiese gaping tussen Skepper en skepping binne-wêrelds te verstaan en God eenvoudig oral in tyd-ruimte teenwoordig te beskou (Peacocke 2002:110). Met behulp van 'n Venn-diagram verduidelik hy dan ook hierdie dinamiese ontluikende netwerk. Die menslike bewussyn word analoog hieraan verduidelik: sinapse $\leftrightarrow$ neurone $\leftrightarrow$ netwerk $\leftrightarrow$ kaarte $\leftrightarrow$ sisteme $\leftrightarrow$ brein $\leftrightarrow$ bewussyn (Peacocke 2002:113). Ek meen dit is ook baie wat Popper (2000) wil bereik met sy drie wêrelde begrip:

We cannot understand world 2, that is the world inhabited by our own mental states, without understanding that its main function is to produce world 3 objects, and not to be acted upon by world 3 objects. For world 2 interacts not only with world 1 , as Descartes thought, but also with world 3; and world 3 objects can act upon world 1 only through world 2 , which functions as an intermediary. (bl. 7)

Panenteïsme word dalk duideliker as ons eien wat Moltmann (1980:111) bedoel wanneer hy sê dat die eenheid van die Triniteit nie 'n numeriese getal een is nie, maar ' $n$ uniekheid en geleë is nie in 'n enkele subjek nie, maar in 'n subjektiewe gemeenskap. Dit moet dus nie soseer as 'n Drie-eenheid verstaan word nie, maar as 'n Drie-enigheid.

\section{Ontluikende gemeenskap en geheelskap}

Celia Dean-Drummond (2006), professor in teologie asook in biologie aan die Universiteit van Chester, skryf die volgende:

Wisdom is like a search of the soul, so such a search is not 'detached' from our biological make up, even if wisdom as a complex cultural capacity goes beyond biological programming. (bl. 86)

Eugène Marais het met sy navorsing op miere 'n 'geheim van die wêreld' ontbloot wat inderdaad van kenteoretiese belang vir ook die teologie kan wees. Sy tese is dat die mier nie atomisties ontleed moet word nie, maar wel korporatief te eien is en dat die termiethoop inderdaad 'n enkele dier is waarvan die funksies van die onderskeie ledemate deur verskillende klasse in die termietkolonie uitgevoer word: een klas is die mond en voedingstelsel, ' $n$ ander is die kloue of horings vir verdediging en ' $n$ ander is die geslagstelsel (Marais 2007:24). En die belangrike, die koningin is die brein van hierdie liggaam en vorm die 'psigologiese middelpunt' (Marais 2007:118). Wanneer die koningin gedood word, sterf ook ál die miere in die nes. In kort, die termietnes is ' $n$ 'voorbeeld van die samestelling en wording van hoogs ontwikkelde en komplekse diere soos die soogdiere' (Marais 2007:60).

In terme van die onderhawige tema, is 'n ander saak van die termietnes fassinerend. Slegs die koningin kan voortplant en sy begin die totale nes nadat sy haar vlerke verloor het. Self werk sy egter nooit nie, dit doen die ander. Die merkwaardige is nou dat die werkers en soldate ' $n$ lang reeks omgewingsherinnerings erf van haar wat dit self nooit gehad het nie. En omgekeerd, erf hulle ook geen spesiale eienskap van hulle voorsaat nie (Marais 2007:112). Dit beteken dat die totale gedrag van die enkele mier van buite bestier en gedetermineer word. Die koningin beskik oor 'n 'besturende mag' of 'morele band' (Marais 2007:112). Hierdie verskynsel is alleen korporatief of kollektief te verklaar. Op onverklaarbare gronde vind kommunikasie in hierdie organisme plaas (selfs deur 'n staalplaat heen wat in die middel van ' $n$ miershoop ingekap is). Die gedrag van die termiete is dus nie in die gene vasgelê nie soos die geelvinke wat vir vier geslagte onder kanaries uitgebroei is, geen wurm of geelvinkneste gesien het nie, maar steeds 'n tipiese geelvinknes kan vleg wanneer die geleentheid hom voordoen (Marais 2007:107). Gedrag by die miere woord dus 'voorgesê'. In 'n miernes van bedrywighede is die koningin die 'groepsiel' (Engels: communal mind) wat dus sowel lewe as kommunikasie moontlik maak.

Marais (2007) waag om hieruit selfs metafisiese kontoere te trek:

Daaruit ontstaan die hoop dat daar 'n algemene groot doel in die Natuur is en dat dit bestier word deur ' $\mathrm{n}$ siel gelyksoortig, maar oneindig meer ingewikkeld as die primêre siel. (bl. 74)

Netso min as wat 'n mier die mens kan gewaar wat sy lewensloop kan beïnvloed, meen Marais, kan die mens ook die 'primêre siel' waarneem wat alles transendeer. Sover gaan ek egter nie, maar Marais se vertrekpunt en die ontluikende gemeenskap en geheelskap is wel belangrik.

Dit sluit aan by 'n al hoe duideliker besef dat die mens eintlik eksentries is en dat baie van ons voorskrifte buite ons bewussyn plaasvind. Baie keuses en optredes geskied eintlik spontaan en kan 'n mens selfs waag om in plaas van 'n onderbewussyn, te praat van 'n sonderbewussyn! (Dingemans 2012:6). Die menslike identiteit is die produk van sowel biologiese as omgewingsfaktore. Dit is opmerklik dat twee van die voorste denkers in teologiese antropologie vandag, die mens konsistent 'eks-sisterend' (uit sigself tree) binne 'n netwerk verstaan. In sy reeks, The matrix of Christian Theology, wil Stanley Grenz byvoorbeeld antropologie binne 'n groter netwerk van 'n Trinitariese Godsbegrip plaas. The social God and the relational self wil eventueel die imago Dei as 
'n eskatologiese konsep hanteer wat uitloop op die 'Global Soul' (Grenz 2001:3). Dit gaan dus vir hom om die ommekeer weg van 'n egosentrisme na 'n gemeenskapsgebaseerde siel wat dan 'n raamwerk of matrys vorm om die werklikheid te verstaan. Die sosiale Triniteit vorm die 'root metaphor' vir alle verstaan. Ook David Kelsey (2009) wil met sy eksentriese verstaan van die imago Dei waar skepping, herskepping en versoening 'n drievoudige, maar tegelyk ook 'n paradigmatiese heliks vorm, die mens biologies (heliks) en kultureel in 'n groter geheel inbind.

Die optiek van hierdie artikel - Spreuke 6:6 - vra inderdaad na die wysheid in die skepping. John Ray het met sy boek, The wisdom of God manifested in the glory of creation (1695) geoordeel dat 'n noukeurige studie van die natuur ons 'n beter insig in God se wysheid gee. Dit herinner ook aan die Nederlandse Geloofsbelydenis se Artikel 2 wat van die 'twee boeke' van God praat. ${ }^{4}$ Maar dit dink ek is juis die tipiese debat van 'n natuurlike teologie wat ek as agterhaal beskou. Dalk sê Moltmann (2003:148) duideliker wat ek probeer oordra wanneer hy openbaringsteologie met wysheidsteologie by wyse van die volgende skemas vergelyk: God $\rightarrow$ mens $\rightarrow$ natuur (openbaringsteologie) en God $\rightarrow$ natuur $\rightarrow$ mens (wysheidsteologie). Die wisseling lê by die laaste twee skakels en nie by die eerste nie: 'Wysheid begin met die dien van die Here; wie die Heilige ken, het werklik insig' (Spr 9:10). Geloof in God was ook die vooronderstelling by Thomas Aquinas:

Hence it remains that grace, as it is prior to virtue, has a subject prior to the powers of the soul, so that it is in the essence of the soul. For as man in his intellective power participates in the Divine knowledge through the virtue of faith, and in his power of will participates in the Divine love through the virtue of charity, so also in the nature of the soul does he participate in the Divine Nature, after the manner of a likeness, through a certain regeneration or re-creation. (Thomas, STh., I-II q.110 a. 4 resp.)

Dean-Drummond (2006:67) merk na 'n bespreking van die boek Job op dat 'n evolusionêre konvergensie op alle vlakke in die natuur plaasvind en dat daar 'n soort 'natuurlik wysheid' is wat ook vir die teologie betekenis inhou:

Convergence is a language about evolution that opens up the window once more for biologists to explore the concept of purpose, just as natural law opens up a window once more for theologians to affirm biological insights as having significance. (Deane-Drummond 2006:72)

Sy oordeel dat 'Natural Law' en 'Eternal Law', mekaar wedersyds net kan verryk. Maar wanneer dit sou versmelt, het ons met ' $n$ naturalisme te doen. Helaas is dit die keuse wat Wesley Wildman uitoefen, alhoewel ek 'n naturalisme nie wil nie, kan ek volmondig saamstem wanneer hy beweer dat '... human beings are religious and spiritual creatures not only historically, culturally, and circumstantially,

4.Artikel 2: "Ons ken Hom deur twee middele: Ten eerste deur middel van die skepping, onderhouding en regering van die hele wêreld. Dit is immers voor ons oë soos 'n mooi boek waarin alle skepsels, groot en klein, die letters is wat ons die onsigbare dinge van God, naamlik sy ewige krag en goddelikheid, duidelik laat sien,
soos die apostel Paulus sê. Al die dinge is genoegsaam om die mense te oortuig en hulle alle verontskuldiging te ontneem. Ten tweede maak Hy Hom deur sy heilige en Goddelike Woord nog duideliker en meer volkome aan ons bekend, en wel so en Goddelike Woord nog duideliker en meer volkome aan ons bekend, en wel so
veel as wat vir ons in hierdie lewe nodig is tot sy eer en tot saligheid van hulle wat aan Hom behoort. but also ontologically, essentially and inescapably' (Wildman 2009:218).

Wysheid funksioneer binne sowel 'n biologiese as 'n kulturele nis, dit sowel geneties as memeties (Dawkins 2006:191201). Daarom word dit ontvang, maar ook aangeleer. Die punt moet duidelik wees: wysheid kan ook blootgelê word. Dit sluit goed aan by Welker (1999) wanneer hy oor die skeppingsverhale sê:

the earth is rather an active, empowering agent that brings forth life in the form of various interdependent processes of selfreproduction. At the same time, the earth is to be understood as environment of various heterogeneous life-processes. (bl. 42).

Die vierdelige indeling van Ian Barbour (2005:21) om die verhouding tussen teologie en wetenskap te verduidelik, is alombekend: konflik, onafhanklikheid, dialoog en integrasie. Kritiek is dikwels uitgespreek omdat die onderskeidings te vaag is. Tog volhard iemand soos John Haught (2012:9) om dit eerder nog wyer te maak en volstaan hy met net drie onderskeidinge: konflik, kontras en konvergensie. Dit mag minder genuanseerd wees as Ted Peters (2000) se agt opsies, maar is tog veel meer werkbaar. Konvergensie wil duidelik' $n$ beweging aandui en oorstyg konflik en kontras. 'Convergence, however, rejects such astounding displays of literalism and looks for a much more nuanced way of relating scientific discoveries to faith and theology' (Haught 2012:31). Konvergensie is wat my betref, juis ook 'ontluikende gemeenskap en geheelskap.'

Bas C. van Fraassen (1980) se konstruktiewe empirisme bied 'n werkbare epistemologie om bogenoemde konvergensiemodel te ondersteun. Die vertrekpunt is die klem op 'n epistemiese gemeenskap met 'n gemeenskaplike metodiek en gedeelde waardes. Die integriteit van die individuele lede moet bo verdenking wees. So 'n wetenskaplik homogene groep navorsers neig ook om met dergelike groepe saam te werk en dit bring Hiskes (2002) by haar tese uit:

I will argue that the empirical orientation and critical attitudes of constructive empiricism are prima facie religion-friendly and could in principle provide a framework that can support and encourage an epistemic community that includes both committed Christians and committed scientists. (bl. 241)

In plaas van positivistiese uitsprake, word ag geslaan op menslike kognisie, refleksie en waardes. Dit gaan daarom nie om ' $n$ wedywering na waarheid nie, maar om 'n geleentheid om mense se verstaan van die voorhande wêreld wedersyds te verryk. Dit klop met die natuurlike wysheid wat ons van die termietnes kan opdoen: 'More important, perhaps, wisdom as cognition implies a way of integrating different interpretations, rather than simply accumulating more information' (DeaneDrummond 2006:83). Die kriteria wat geld is konsistensie en koherensie (Hiskes 2002:248). Daarom is dit geregverdig om oorgeërfde en oorgelewerde kognitiewe eienskappe te verreken. William Alston verkies ook om eerder te praat van epistemiese verantwoording as van kennis (Alston 1993:2).

Is ons hiermee nou by 'n denkwêreld voor Kant? Iemand soos Richard Rorty met sy radikale antirealisme sou dit waarskynlik meen. Hy bepleit 'n filosofie 'sonder spieëls' 
(Rorty 1980:295) asof dit moontlik sou wees om hoegenaamd die werklikheid objektief te weerkaats en hoe blinker die spieël, hoe getrouer die weergawe. In twee opsigte gaan Rorty wel verder as Kant. Eerstens verwerp hy 'n noumenale werklikheid en tweedens omvorm hy Kant se enkelvoudige denkkategorieë na 'n pluraliteit van konseptuele idees (Alston 2002:2). Hiermee bedoel Rorty dat epistemologie eerder hermeneutiek word waar die betrokkenes 'n bepaalde societas en waardes ('civility') gemeenskaplik het (Rorty 1980:318). Maar dit doen ek nie. Ek is geen antirealis nie, maar ook geen idealis nie.

Hierdie aspek sluit nóú aan by die konstruktiewe empirisme wat tot oortuiging kom dat die Skepper inderdaad skepping word.

\section{Slotsom}

Die vertrekpunt van hierdie betoog was die vraag of daar meer in die skepping is as wat bloot empiries waarneembaar is. Is daar met ander woorde in die skepping inherente wetmatigheid wat ontologies ook bydra tot ons werklikheidsverstaan? Kortom, kan (of moet) byvoorbeeld die kwantumfisika se beginsels van die golfpartikel dualisme of die onbepaalbaarheid ook prinsipieel deel van die gelowige se werklikheidsverstaan vorm? Kan (of moet?) die prinsipiële gemeenskap van die termietnes konstitutief ook vir ons werklikheid wees? Dit wil dus verder gaan as Sally McFague se metaforiese teologie omdat dit ook ontologies met die werklikheid wil omgaan. Die 'meer as' het vir McFague duidelik transendente betekenis. God oorstyg altyd ons spreke en begrip. Die gelyk aan $(=)$ is vir haar tegelyk ook 'n ongelyk aan $(\neq)$. Die 'meer as' in genoemde twee openingsaanhalings aan die ander kant weer, het 'n duidelike immanente betekenis. Dit wil eerder 'n ontologiese uitspraak oor die wêreld maak en sekerlik ook oor die kennende mens. Dit wil dus nie net in beeldspraak oor die werklikheid praat nie, maar konkreet soos die werklikheid dan kwansuis is.

Uiteraard bring dit die kwessie van die verhouding tussen Skepper en skepping in spel. Dit is duidelik dat die klassieke verstaan van 'n substantiewe ontologie hierdie debat in die Reformatoriese teologie gedikteer het en onbewustelik ook, so die drieverdieping wêreldbeeld om God se transendensie en immanensie te beskryf. Die natuurwetenskappe het hierdie wêreldbeeld egter opgehef en filosofie en die OostersOrtodokse teologie het weer hierdie ontologie gerelativeer. Die syn realiseer in relasies en God is nie, maar gebeur. 'n Korrekte kwalifikasie van panenteïsme hef nie op dat God meer is as die skepping nie.

Die wysheidsliteratuur maak ons veral bewus van God se teenwoordigheid in die skepping. Dit plaas klem op die werking van die Gees. Dit is nie nuut in die teologie nie, maar wel verwaarloos in die twintigste eeu se Reformatoriese teologie. Irenaeus (1997) het byvoorbeeld al geoordeel dat die wysheid eerder met die werking van die Gees as met die van die Logos geïdentifiseer moet word:
I have also largely demonstrated, that the Word, namely the Son, was always with the Father; and that Wisdom also, which is the Spirit, was present with Him, anterior to all creation. (bl. 488)

Die Logos en wysheid werk parallel in die skepping, soos die twee hande van God. Augustinus (1997) weer, het wysheid egter Trinitaries verstaan:

Therefore the Father is light, the Son is light, and the Holy Spirit is light; but together not three lights, but one light. And so the Father is wisdom, the Son is wisdom, and the Holy Spirit is wisdom, and together not three wisdoms, but one wisdom: and because in the Trinity to be is the same as to be wise, the Father, Son, and Holy Spirit, are one essence. Neither in the Trinity is it one thing to be and another to be God; therefore the Father, Son, and Holy Spirit, are one God. (bl. 109)

Eugène Marais se waarneming van miere en die gevolglike kollektiewe aard van die siel van die mier, vind ons dus nie net analoog aan die mens se gemeenskapsaard nie, maar ook bepalend vir ons werklikheidsverstaan. Hierdie sinergie is ' $n$ induktiewe groeiproses wat duidelike biokulturele trekke openbaar. Hierdie eko-kulturele nis soos ek verkies om dit eerder te bestempel (Buitendag 2012c), het natuurlik raakvlakke met die Postliberale Teologie en veral ook met 'n evolusionêre antropologie. Omdat dit in die grond geaard is, is dit ook nie resloos gelyk aan Peter Berger (1990) se simboliese universum of 'sacred canopy' nie.

Die twee openingsaanhalings se vraag na die 'meer as' kan dus inderdaad in die affirmatief beantwoord word, maar soos dit geblyk het wel in terme van 'n werklikheidsverstaan met ' $n$ geïntegreerde epistemologie en ontologie wat nie liniêr-chronologies uitgepak moet probeer word nie. Zohar en Marshall se 'I believe' in die eerste aanhaling gee tereg subjektiewe indrukke te kenne, alhoewel die bedoeling duidelik is: so is die werklikheid en nie so lyk die werklikheid nie. 'n Vorm van realisme word dus voorgestaan waar relasionaliteit konstitutief is. Ons het hier nie net met 'taligheid' te doen nie, maar met 'n diskursiewe epistemiese aangeleentheid.

'n Epistemiese gemeenskap van teoloë én natuurwetenskaplikes kan inderdaad bydra tot ons werklikheidsverstaan. Wat ek bepleit is dat teologie kan put uit natuurwetenskaplike insigte oor die werklikheid en omgekeerd, pretensieus soos dit mag oorkom, ook kan bydra tot hierdie onderneming. Waarheid word dan ook verkieslik met begrip vervang. Ons soek nie die waarheid nie, ons probeer verstaan. Dit is ' $n$ kollektiewe aksie en die proses is konvergerend.

\section{Erkenning Mededingende belange}

Die outeur verklaar dat hy geen finansiële of persoonlike verbintenis het met enige party wat hom nadelig kon beïnvloed in die skryf van hierdie artikel.

\section{Literatuurverwysings}

Allen, D., 1985, Philosophy for understanding theology, John Knox Press, Atlanta. Alston, W.P., 1993, Perceiving God: The epistemology of religious experience, Cornell University Press, London. PMCid:2619342 
Alston, W.P. (ed.), 2002, Realism \& Antirealism, Cornehl University Press, New York, NY.

Augustine, A., 1997, 'On the Holy Trinity', in P. Schaff (ed.), The Nicene and Post-Nicene Fathers, vol. III, electronic version, pp. 104-114, Logos Research Systems, Oak Harbor, WA.

Barbour, I., 2005, 'Ways of relating science and theology', in R.J. Russel, W.R. Stoeger \& G.V. Coyne (eds.), Physics, Philosophy and Theology, pp. 21-48, Vatican Observatory, Vatican, Vatican City State.

Barr, J., 1994, Biblical faith and natural theology, Clarendon Press, Oxford. http:// dx.doi.org/10.1093/0198263767.001.0001

Barth, K., 2004, Church dogmatics: The doctrine of creation, CD-ROM edn., vol. III.4, transl. G.W. Bromiley \& T.F. Torrance, T. \& T. Clark, Edinburgh.

Berger, P.L., 1990, The sacred canopy, Anchor Books, New York, NY

Boff, L., 2000, Holy Trinity, perfect communion, Orbis Books, Maryknoll, NY. PMid:10854681

Buitendag, J., 2012a, 'A conversational reflection on Luco van den Brom's understanding of time and space', Kerk en Theologie 64, 136-146.

Buitendag, J., 2012b, 'Epistemology models ontology'- In gesprek met John Polkinghorne, HTS Teologiese Studies 67(1), Art. \#897, 9 pages. http:// dx.doi:10.4102/hts.v67i1.897

Buitendag, J., 2012c, 'Die noodsaaklikheid van habitat in ons definisie van menswees: Op soek na 'n eko-teologiese verstaan van menslike lewe', HTS Teologiese Studies 68(1), Art. \#1283, 8 pages. http://dx.doi.org/10.4102/hts.v68i1.1283

Clayton, P., 2004, 'Panentheism in metaphysical and scientific perspective', in P. Clayton \& A. Peacocke (eds.), In whom we live and move and have our being, pp. 73-91, William B Eerdmans Publishing House, Grand Rapids, MI.

Dawkins, R., 2006, The God delusion, Bantam Press, London.

Deane-Drummond, C., 2006, Wonder and wisdom, Templeton Foundation Press, Philadelphia, PA.

Dingemans, G., 2012, Het brein geeft de denken, ePub edn., Free Musketeers, viewed from http://www.mybebook.com/het-brein-geeft-te-denken.html

Fischer, S. \& Grohmann, M. (eds.), 2010, Weisheit und Schöpfung. Festschrift für James Alfred Loader zum 65. Geburtstag, vol. VII, Peter Lang, Frankfurt am Main.

Gregersen, N.H., 2004, 'Three varieties of panentheism', in P. Clayton \& A. Peacocke (eds.), In whom we live and move and have our being: Panentheistic reflection on God's presence in a scientific world, pp. 19-35, William B Eerdmans Publishing Company, Grand Rapids, MI.

Grenz, S.J., 2001, The social God and the relational self, Westminster John Knox Press, Louisville.

Habel, N., 2004, 'Design, diversity and dominion: Biodiversity and Job 39', Interface: A Forum for Theology in the World 7(1), 55-64.

Haught, J.F., 2012, Science and Faith, Paulist Press, New York, NY. PMid:22421128

Hawking, S., 2001, The universe in a nutshell, Bantam Press, London.

Hawking, S. \& Mlodinow, L., 2010, The grand design, Bantam Press, London. PMid:20923131

Heim, K., 1926, Glaube und Leben. Gesammelte Aufsätze und Vorträge, Furche, Berlin.

Hiskes, A.L., 2002, 'Van Fraassen's construtive empiricist philosophy of science and religious belief: Prospects for a unified epistemology', in W.P. Alston (ed.), Realism \& antirealism, pp. 238-252, Cornell University Press, London.

Irenaeus, 1997, 'The apostolic fathers with Justin Martyr and Irenaeus (521)', in A Roberts, J. Donaldson \& A.C. Coxe (eds.), The Ante-Nicene Fathers: Translations Roberts, J. Donaldson $\&$ A.C. Coxe (eds.), The Ante-Nicene Fathers: Translations
of the writings of the Fathers down to A.D. 325, vol. I, electronic version, n.p., of the writings of the Fathers down to A.D. 325, vol. l, electronic version, n.p.,
The Apostolic Fathers with Justin Martyr and Irenaeus, Logos Bible Software, Oak Harbor, WA.
Jüngel, E., 1977, Gott als Geheimnis der Welt, 2nd edn., J.C.B. Mohr/Paul Siebeck,Tübingen.

Kelsey, D.H., 2009, Eccentric existence: Theological antropology, vol. II, WJK Westminster John Knox Press, Louisville, KY.

Marais, E.N., 2002, The soul of the ape, Stephan Phillips (Pty)Ltd, Somerset West.

Marais, E.N., 2007, Die siel van die mier, S.F. Honing, J.C. Kannemeyer, A. Klopper, L. Louw \& M. Oosthuizen (reds.), Protea Boekhuis, Pretoria.

McFague, S., 1982, Metaphorical theology: Models of God in religious language, Fortress Press, Philadelphia, PA.

Michener, R.T., 2013, Postliberal theology, T\&T Clark, Bloomsbury/London.

Moltmann, J., 1980, Trinität und Reich Gottes. Zur Gotteslehre, Chr. Kaiser Verlag, München.

Moltmann, J., 1985, Gott in der Schöpfung. Ökologische Schöpfungslehre, Chr. Kaiser Verlag, München.

Moltmann, J., 1994, The spirit of life: A universal affirmation, transl. M. Kohl, Fortress Press, Minneapolis, MN.

Moltmann, J., 2003, Science \& wisdom, transl. M. Kohl, Fortress Press, Minneapolis, MN.

Peacocke, A., 2002, Paths from science towards God, Oneworld Publications, Oxford.

Peacocke, A., 2004, 'Articulating God's presence in and to the world unveiled by the sciences', in P. Clayton \& A. Peacocke (eds.), In whom we live and move and have our being, pp. 137-154, William B Eerdmans Publishing Company, Grand Rapids, MI.

Peters, T., 2000, 'Theology and Natural Science', in D.F. Ford (ed.), The modern theologians, pp. 649-668, Blackwell Publisher, Oxford. PMid:11131551

Plantinga, A., 2011, Where the conflict really lies: Science, religion, \& naturalism, Oxford University Press, Oxford. http://dx.doi.org/10.1093/acprof: so/9780199812097.001.0001

Polkinghorne, J., 1998, Science \& theology, Fortress Press, Minneapolis, MI. PMid:11806416

Polkinghorne, J., 2005a, Quarks, chaos \& Christianity, The Crossroad Publishing Componay, New York, NY.

Polkinghorne, J., 2005b, 'The quantum world', in R.J. Russel \& G.V. Coyne, Physics, philisophy and theology, pp. 333-342, Vatican Observatory, Vatican City.

Popper, K., 2000, Knowledge and the body-mind problem, Routledge, London.

Rorty, R., 1980, Philosophy and the mirror of nature, Princeton University Press, Princeton, NJ.

Schwöbel, C., 1995, 'The renaissance of trinitarian theology: Reasons, problems and tasks', in C. Schwöbel (ed.), Trinitarian Theology Today, pp. 1-30, T\&T Clark, London.

Thomas, A.S., 2009, Summa Theologica. I, transl. Fathers Dominican, Logos Research Systems, Inc., Bellingham, WA.

Torrance, T.F., 1997, Space, time and incarnation, T\&T Clark, Edinburgh.

Trundle, R.C., 1994, Ancient Greek Philosophy: Its development and relevance to our time, Avebury Ashgate Publishing Company, Aldershot, GU. PMid:8027158

Van Fraassen, B.C., 1980, Scientific image, Oxford University Press, New York, NY. http://dx.doi.org/10.1093/0198244274.001.0001

Versfeld, M., 2010, Our selves, E. Wolff (ed.), Protea Boekhuis, Pretoria.

Welker, M., 1994, God the Spirit, transl. J.F. Hoffmeyer, Fortress Press, Minneapolis,

Welker, M., 1999, Creation and reality, transl. J.F. Hoffmeyer, Fortress Press, Minneapolis, MN.

Wildman, W.J., 2009, Science and religious anthropology, Ashgate, Surrey.

Zizioulas, J.D., 2006, Communion \& Otherness, T. \& T. Clark, London.

Zohar, D. \& Marshall, I., 1994, The quantum society: Mind, physics and a new vision, Flamingo HarperCollins Publishers, London. PMCid:45380 